\title{
Animal Models of Psychiatric Disorders: A Literature Review
}

\author{
Arnavi Patel, BA Student [1]*
}

[1] Department of Psychology, Wilfrid Laurier University, Waterloo, Ontario, Canada, N2L3C5

*Corresponding Author: pate7120@mylaurier.ca

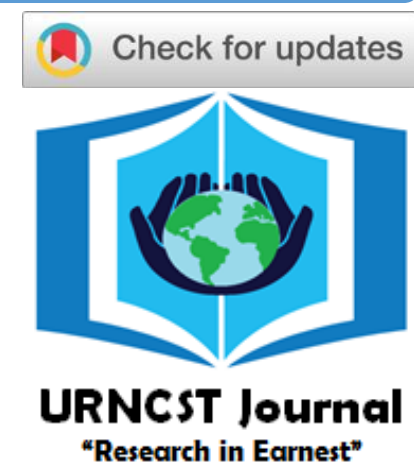

\begin{abstract}
Introduction: Animal models have been used in many areas of research to provide insights into mechanisms and treatments for various disorders and diseases. For example, animals are often used in other areas of psychology, such as learning, with examples such as Pavlov's dogs and Skinner's rats. Further, animals have also been noted to exhibit psychiatric disorders that are frequently observed in humans, such as depression and anxiety. However, the use of animal models in other less studied fields of psychiatric research is unclear. This poses the questions: is the use of animals effective in studies of common mental health disorders? If so, what aspects of common mental health disorders do current studies focus on? Further, can disorders that have lower prevalence rates also be studied with the use of animals? This paper reviews the use of animals in the study of obsessive-compulsive related disorders of addiction, eating disorders, and trichotillomania (a disorder of compulsive hairpulling) to answer these questions.

Methods: Addiction, eating disorders, and trichotillomania were examined based on ease of study in non-human animals, and sufficient available literature. Nine articles for each disorder were examined to determine types of animals used, and the purpose of animal models in the study.

Results: Research shows animal models are often used to study the etiology, genetics, mechanisms, and neurochemistry of psychiatric disorders. Animal models have high validity and translate well to humans. However, treatments of psychiatric disorders are less studied using animal models.

Discussion: The review of the current literature suggests animal models are effective in studies of addiction, eating disorders, and trichotillomania. Animal models can be developed to inform various aspects of psychiatric disorders and should be expanded to include studies examining treatments as well. Further, food addiction also should be further assessed using animal models.

Conclusion: Overall, animal models are useful in studying various aspects of psychiatric disorders and should continue to be used for those less commonly studied. Future studies with animal models should focus on psychiatric disorders that involve compulsive, repetitive behaviours.
\end{abstract}

Keywords: addiction; trichotillomania; eating disorders; animal models; mental illnesses; psychology; genetics; etiology; behaviour; treatment

\section{Introduction}

The use of non-human animals to study human diseases and disorders began during the late sixteenth and early seventeenth century, when Dr. William Harvey described the human circulatory system through his work with fish, such as eels, chicks, and pigeons. In the current era, animal modeling has evolved beyond simple observation to manipulating genomes of mice. Scientists have been able to create transgenic mice (i.e., mice with additional genomes) and knockout mice - (i.e., mice lacking certain genes) - to better study the effects of different genes [1].

Animal models have been used in many areas of biology for many different purposes. Often, animal models are used in areas of research in which it is hard to obtain human samples; this enables a better understanding of the physiology and mechanisms of the disease, and testing for new treatments. For example, studies of intervertebral disc degeneration (IVD) and cancer have used dogs and rats to identify possible mechanisms, treatments, routes of treatment administration, and biological endpoint markers $[2,3]$. Results from animal model trials are often highly correlated with human trials [4] which suggest that animal models are an effective way to test treatments for humans.

The importance of animal models in the study and treatment of various disorders and diseases is evident even in psychiatric research. Outside of the lab, mental disorders have been identified in birds, and canines. Firstly, feather 
UNDERGRADUATE RESEARCH IN NATURAL AND CLINICAL SCIENCE AND TECHNOLOGY (URNCST) JOURNAL Read more URNCST Journal articles and submit your own today at: $\underline{\text { https://www.urncst.com }}$

picking has been described as one of the most challenging and common behaviours in pet birds [5]. Often, feather picking is noted as a method of self-grooming, however this behaviour can sometimes be excessive and lead to tissue damage as well as the prevention of normal growth. Feather picking in birds is commonly compared to obsessive compulsive disorder (OCD) in humans and is also comparable to trichotillomania, a disorder characterized by compulsive hair-pulling often resulting in hair loss [5]. Second, a study revealed that $73 \%$ of dog owners reported that their dogs demonstrated PTSD-like symptoms [6]. Therefore, animal models of mental illness in nonhuman animals can possibly help identify the mechanisms, etiology, and treatments for common human psychiatric disorders. Although the presence psychiatric disorders have been documented in animals, it is unclear how informative animal models are to humans across various psychiatric disorders.

Countless studies over the years have used animals in research in many areas of psychology. Examples such as Pavlov's dogs, Skinner's pigeons, and studies using rats in radial mazes show the importance of using animals in research. Additionally, the use of animal models has been extended to the study of mechanisms and treatments involved in common psychological disorders. Currently researchers have started the use of animal models in some of the most common mental disorders such as anxiety and depression [7]. Research on non-human animals has also led to the development of genetic, pharmacological, and behavioural models of OCD. Non-human animal studies have been crucial in identifying the various mechanisms that underlie each disorder, testing novel pharmacological treatments, and studying behaviours that resemble psychological disorders [8].

Animal models serve a unique purpose in the study of human diseases and disorders, and their application can be extended to psychiatric and clinical uses as well. Currently, the research regarding mental health and nonhuman animals focuses mainly on common mental health disorders. Is the use of animals effective in studies of common mental health disorders? If so, what aspects of common mental health disorders do current studies focus on? Further, can disorders that have lower prevalence rates also be studied with the use of animals? This paper reviews the current literature available regarding animal models in psychiatric research. This paper will pay particular focus on two mental illnesses that are commonly occurring in the human population and well studied, and one metal illness that is less prevalent and not as well studied. The usefulness of animal models in the research of these disorders will also be discussed.

The review will begin with examining the use of animal models in the study of addiction, or otherwise known as substance use disorders. Substance use disorders are a commonly occurring disorder in the human population, with a 12 -month prevalence rate of $3.9 \%$ and a lifetime prevalence rate of $9.9 \%$ [9] and are relatively well studied in non-human animals. Substance use disorders encompasses a range of disorders that involve the use of substances such as alcohol, caffeine, cannabis, hallucinogens, inhalants, and opioids among others [10]. Furthermore, eating disorders will also be discussed in this paper. Eating disorders are common among humans, and include anorexia nervosa, bulimia nervosa, and binge eating disorder. Anorexia nervosa is characterized by restrictions in energy intake resulting in low body weight, accompanied by intense fear of gaining weight, disturbances in the way body weight and shape is experienced, the influence of body weight and shape on self evaluation, and lack of recognition for the seriousness of the low body weight [10]. The DSM-V estimates the 12-month prevalence rate of anorexia nervosa to be $0.4 \%$, and it is diagnosed in females more often than in males [10]. Similarly, bulimia nervosa also includes fear of gaining weight and the influence of body weight on self evaluation however bulimia nervosa also includes period of binge eating followed by compensatory behaviours to prevent gaining weight [10]. Binge eating periods involves eating a large amount of food in a certain amount of time and a sense of lack of control. These periods are followed by behaviours such as vomiting and using laxatives to prevent weight gain from the food consumed [10]. Bulimia nervosa is estimated to have a 12month prevalence of $1-1.5 \%$ with more females experiencing it than males [10]. Lastly, binge eating disorder is characterized as repetitive periods of binge eating followed by compensatory behaviors, often accompanied by distress regarding binge eating periods [10]. Unlike bulimia nervosa binge eating disorder also involves eating more rapidly, eating until feeling uncomfortably full, eating when not hungry, eating alone due to embarrassment of how much one is eating, and feeling embarrassed, guilty, and depressed after an episode [10]. The 12-month prevalence for binge eating disorder is estimated to be $1.6 \%$ for females and $0.8 \%$ for males [10]. However, research into its etiology and treatments are often overlooked. The use of animal models to assess etiology and treatments of eating disorders will be discussed in this paper. Lastly, trichotillomania is an often overlooked disorder and not well studied. Trichotillomania, also known as hair-pulling disorder, is characterized by repeatedly pulling out causing hair loss, and leading to distress in important parts of life such as social and occupational [10]. The DSM-V estimates the 12-month prevalence rate of trichotillomania to be $1-2 \%$, with females experiencing it more often than males [10]. Animal models may similarly provide insight into the etiology and possible treatments for trichotillomania. With these disorders, this paper aims to determine the extent to which animal models can be used to inform psychiatric research in humans. 
UNDERGRADUATE RESEARCH IN NATURAL AND CLINICAL SCIENCE AND TECHNOLOGY (URNCST) JOURNAL Read more URNCST Journal articles and submit your own today at: https://www.urncst.com

\section{Methods}

Disorders examined were based on prevalence, ease of study in non-human animals, and how well-studied they are based on current literature. Disorders that appear to be unique to humans such as sexual disorders, body dysmorphic disorders, and gender dysmorphic disorders were excluded due to lack of research using animal models. With these disorders being discluded, mood disorders, anxiety disorders, trauma related disorders, obsessivecompulsive disorders, substance use disorders, and eating disorders were considered possibilities for research in this review.

Obsessive-compulsive related disorders, substance use disorders, and eating disorders have similarities in terms of the obsessive-compulsive nature they share. Therefore, mood disorders, anxiety disorders, and trauma related disorders were excluded from this review. Substance use disorders and eating disorders were chosen to be reviewed under an umbrella term, since specific disorders that fall within these umbrella terms are very similar. Further, a preliminary search of the available literature showed most literature groups the specific disorders under the umbrella terms. Obsessive compulsive related disorders include OCD, hoarding disorder, excoriation, and trichotillomania [10]. However, unlike the literature for substance use disorders and eating disorders, the available literature does not tend to group the four disorders under one term. A preliminary search revealed there is sufficient research available on the four disorders separately to conduct a review for this paper. According to prevalence rates provided in the DSM-V, OCD and trichotillomania had the lowest prevalence between the four disorders $(1.2 \%$ and $1-2 \%$ respectively) [10]. However, trichotillomania is a less studies disorder. To answer the questions of whether animal models can be used in the study of less studied and less prevalent disorders, trichotillomania was chosen as a disorder to be revied in this paper.

Once the disorders to be studied were finalized, the search, inclusion, and exclusion criteria were created to find research articles. The search criteria included the terms "animal models of [trichotillomania/eating disorders/addiction]" and "are animal models of [trichotillomania/eating disorders/addiction] useful". The first search criteria helped to identify the general use of animal models for studying the chosen disorders, and the second search criteria helped determine specifically the usefulness of animal models for furthering our understanding of the chosen disorders. Both search terms were entered in Google Scholar; this was the only search engine used for data collection. From the search results, the review included the first nine papers that discussed animal models of substance use disorders and eating disorders, and the first eight articles which discuss trichotillomania relating the findings from animal studies to humans. From each article, information about the disorder studied, animal(s) used, purpose of the animal study, and its implications to humans were extracted. This information was used to qualitatively examine the overall effectiveness of animal models in studies of substance use disorders, eating disorders, and trichotillomania.

\section{Results \\ Substance Use Disorders}

To review the use of animal models in the study of addiction, nine articles were identified. All articles that were explored in this review, used rat or rodent models. Eight articles conclude that animal models in addiction studies are effective in understanding the etiology these disorders, while only one concludes that animal models are not effective. The one article in disagreement states animal models developed for understanding addiction are ineffective as addiction is a uniquely human disorder and cannot be studied in animals [11]. The authors also assert that addiction in humans is a result of operant conditioning rather than compulsion as demonstrated by animal research. Furthermore, addiction/substance use disorders have environmental and social components which are impossible to simulate in the lab, and animals thus far have not been shown to be useful in understanding addiction [11]. The other eight articles focus on treatments, etiology, brain mechanisms, and the validity of using animal models for addiction research (; ;). Three articles determined animal models are effective in research on treatments for addiction [12-14] while two articles determined animal models are not effective for understanding treatments for addiction $[11,15]$. The other two articles determine animal models of addiction have good face validity, and predictive validity [16-17]. An interesting finding from Hilderbrand \& Lasek (2018) indicated sex differences in the brain are poorly understood in addiction research, and females are often underrepresented in the literature. Further, Sovik \& Barron (2013) suggest addiction research should consider using invertebrates in animal models as they provide a diverse range of tools for understanding the neuroanatomy and molecular underpinnings of addition. Animal models have also been used to study an interesting type of addiction, food addiction in particular [19]. The determinants and consequences of food addiction can be studied using selfadministration procedures and studying addiction-like behaviours in animals.

\section{Eating Disorders}

The use of animal models in the study of eating disorders was reviewed by analyzing the findings of nine articles. Eating disorders were explored with the use of rat and rodent models in all articles included in this review. Two articles discuss behavioural models and report they are effective in the study of eating disorders [20,21]. Three models discuss neurobiological models [22-24], and two articles discuss the etiology and development of eating disorders $[25,26]$. Some animal models of eating disorders include lesion studies which have helped identify neural 
UNDERGRADUATE RESEARCH IN NATURAL AND CLINICAL SCIENCE AND TECHNOLOGY (URNCST) JOURNAL Read more URNCST Journal articles and submit your own today at: $\underline{\text { https://www.urncst.com }}$

structures involved in the etiology of eating disorders. The hypothalamus is one such example. The hypothalamus has been implicated as the neural structure which maintains homeostasis in relation to eating [23]. Through lesion studies in animals, structures within the hypothalamus such as hypothalamic ventromedial, paraventricular and dorsomedial nuclei, and the lateral hypothalamus have been identified to be involved in eating disorders [23]. The hypothalamic ventromedial, paraventricular and dorsomedial nuclei have been noted as centres for controlling satiety, and the lateral hypothalamus has been implicated as the hunger centre [23]. Further, animal models of binge eating disorders have also been used to identify alterations in the dopaminergic pathway as a possible etiology of binge eating disorder. Rats that were forced to binge eating sugar showed signs of decreased dopamine release after 36 hours of sugar deprivation [24]. The dopaminergic pathway is associated with a reward system - foods that are palatable are often used to activate this pathway in stressful or negative situations [24]. Desirable foods help alleviate the psychological and physiological effects of stress. However, if this pathway is constantly stimulated it can lead to alterations in dopamine release such that dopamine release will decrease with the absence of desirable foods [24]. This decrease in dopamine can lead to displays of increased anxiety, which was observed in the rats mentioned above [24]. One article mentioned genetic models of eating disorders are not applicable to humans because they do not include some of the important characteristics of eating disorders [27]. The authors claim genetic models of anorexia nervosa, bulimia nervosa, binge eating disorder are not applicable to humans, however models based on stressful life events are. [27], however another article mentions animal models of genes linked to behaviour and mood can help better understand behavioural processes in anorexia nervosa and bulimia nervosa [28]. Most articles merely suggest that future studies focus on treatments and therapies for eating disorders. However, one article provides a possible treatment. van Gestal et al., (2014) found animal models are useful in development of monoaminergic treatments for bulimia nervosa and binge eating disorder. Monoaminergic treatments can also be used for anorexia nervosa, but current research is limited. Overall, the use of animal models in the study of eating disorders appear to be useful for studying the mechanisms and risk factors of eating disorders.

\section{$\underline{\text { Trichotillomania }}$}

Eight articles relating to animal models of trichotillomania were identified. Seven out of eight articles discuss barbering in mice as a possible model for trichotillomania [29-35], three discuss feather picking disorder in birds [32, 35, 36], two discuss hair pulling exhibited in cats [32, 35], and one discusses acral lick dermatitis in dogs, a disorder which is a result of excessive licking of paws or flank causing ulcers [35, 37] Out of the eight articles, only one model was used to investigate treatments relating to trichotillomania, while the rest considered basic research into etiology genetics, and behaviour. All models discussed in the articles reviewed have been translated to trichotillomania in humans. Feather picking in birds is a pathological grooming behaviour in which birds pick off and prevent the growth of feathers [36]. Similarly, mice exhibit a behaviour called barbering in which a dominant mouse will pick whiskers and hairs off of submissive mice [29]. In some cases, mice have been known to pick off their own hair and whiskers [29]. These behaviours are similar to human trichotillomania. Trichotillomania is often triggered by sedentary activities, psychological, or emotional triggers. In birds, feather picking often occurs due to lack of stimulation or environmental enrichment [36]. Furthermore, barbering behaviour in mice is associated with obsessive compulsive behaviours in humans, thus mice models of barbering can be used to further understand trichotillomania and other obsessive-compulsive disorders [30]. Knockout mice and genetic models of barbering in mice have been used to identify possible genes and cortical structures associated with obsessive compulsive behaviours [29, 33-35]. One gene of importance is the Hox 8 gene. This gene is part of the Homeo-box-containing (Hox) genes which are responsible for development. Hox8 is specifically responsible for hair development in mice [29]. Mice with deficient Hox 8 genes have shown barbering behaviour [34]. Similarly, Hox 8 is also implicated in the pathophysiology of OCD in humans [34]. Another gene of importance is the postsynaptic synapse-associated protein 90/postsynaptic density-95-associated protein 3 (SAPAP3). Knockout mice models show an increase in barbering behaviour when deficient in SAPAP3 are found [33]. Similarly, variants of SAPAP3 are also found in humans with trichotillomania which demonstrates its role in manifesting OCD behaviours in humans [33]. Another possible contributing factor of barbering in mice is oxidative stress. N-Acetylcysteine reduces oxidative stress in mice and decreases barbering behaviour [31]. Since mice models of barbering are similar to trichotillomania in humans, N-Acetylcysteine may therefore be a possible treatment for trichotillomania in humans.

\section{Discussion}

The overall literature suggests animal models are effective in studies of obsessive-compulsive related disorders. Animal models can be informative of behavioural, genetic, and neurobiological underpinnings of psychiatric disorders. However, the limited number of articles identified in our search reveal that using animal models for developing treatments for obsessive-compulsive related disorders has not yet been well explored. Almost all the articles covered in this review suggest the next step in animal studies is developing models for treatment of 


\section{UNDERGRADUATE RESEARCH IN NATURAL AND CLINICAL SCIENCE AND TECHNOLOGY (URNCST) JOURNAL}

Read more URNCST Journal articles and submit your own today at: https://www.urncst.com

psychiatric disorders. Existing research has shown that certain non-human animals like mice have several analogous anatomical, neurobiological, and genetic features as humans, and results from animal clinical trials often correlate with clinical human trials $[12,14-17,21,22,24-$ 26, 28-35]. Seeing as many animals are easy to house and study in controlled laboratory environments, researchers have the potential to manipulate and examine specific aspects of disorders. For these reasons, animal models can be effective in studies on treatments of psychiatric disorders including those less commonly observed.

An interesting finding pertaining to addiction and eating disorders is food addiction. Two articles mention food addiction as an eating disorder that closely resembles addiction-like behaviour [19, 21]. Eating disorders have traditionally been associated with a lack of eating or prolonged starvation for a period of time, however compulsive eating has not been studied as well. Animal models have been demonstrated to be effective in the study of food addiction as an eating disorder and an addiction and can further help to better understand food addictions. However, food addictions remain in a gray area. Whether they should be characterized under addictive disorders or eating disorders is still unknown. Based on the current literature it can be argued food addictions should be characterized as substance use disorders due to their compulsive behaviours similar to substance use disorders. However, food is not a category of substance within substance use disorders in the DSM-V. Food addictions also do not share some of the characteristics of other eating disorders such as fear of weight gain, and the influences of body weight on self evaluation. For these reasons, it is hard to categorize food addictions under one disorder. Future research should continue to explore the etiology, genetics, and treatments of food addiction to better categorize this disorder.

While this study aims to provide a short yet comprehensive review of animal models in the use of psychiatric research, it is important to keep in mind some limitations. Only twenty-six articles were reviewed, and the brief literature search may have missed some other relevant articles. Additionally, there are other obsessive-compulsive related disorders which are often overlooked such as excoriation (characterized as excessive picking of the skin often resulting in lesion on the skin [10], and hoarding disorders (characterized as difficulty parting with items [10]. For this reason, the findings of this paper should be viewed as a brief overview of the literature, and not an indepth review.

\section{Conclusions}

Animal models should continue to be used in psychiatric research, as they have helped provide insight into the etiology and mechanisms of addiction, eating disorders, and trichotillomania. However, treatments for these disorders are not yet well studied. Developing animal models or studying treatments for psychiatric disorders is a crucial next step in psychiatric research. Furthermore, the three classes of disorders reviewed in this article are similar in the sense that they involve, compulsive behaviours. This short review suggests animal models are effective in studies of disorders involving compulsive behaviors. The next step in psychiatric research using animal models should focus on other often overlooked psychiatric disorders, particularly those that involve compulsive behaviours.

\section{List of Abbreviations Used}

IVD: intervertebral disc degeneration

OCD: obsessive compulsive disorder

Hox: Homeo-box-containing

SAPAP3: Postsynaptic Synapse-Associated Protein

90/Postsynaptic Density-95-Associated Protein 3

\section{Conflicts of Interest}

The author(s) declare that they have no conflicts of interest.

\section{Ethics Approval and/or Participant Consent}

This study did not need ethics approval because it is a review article. Participant involvement was not needed to complete the article.

\section{Authors' Contributions}

AP: made contributions to the design of the study, collected and analyzed data, and drafted the manuscript.

\section{Acknowledgements}

I would like to thank Janice Yan for her contributions in editing the manuscript and assisting in the design of the study.

\section{Funding}

This study was not funded.

\section{References}

[1] Ericsson AC, Crim MJ, Franklin CL. A Brief History of Animal Modeling. Mo Med. 2013;110(3):201-5. https://www.ncbi.nlm.nih.gov/pmc/articles/PMC39795 91/

[2] Alini M, Eisenstein SM, Ito K, Little C, Kettler AA, Masuda K, et al. Are animal models useful for studying human disc disorders/degeneration? Eur Spine J. 2008 Jan 1;17(1):2-19. https://doi.org/10.1007/s00586-0070414-y

[3] Bergknut N, Rutges JPHJ, Kranenburg H-JC, Smolders LA, Hagman R, Smidt H-J, et al. The dog as an animal model for intervertebral disc degeneration? Spine (Phila Pa 1976). 2012 Mar 1;37(5):351-8. https://doi.org/10.1097/brs.0b013e31821e5665

[4] Steele VE, Lubet RA. The use of animal models for cancer chemoprevention drug development. Semin Oncol. 2010 Aug;37(4):327-38. https://doi.org/10.1053/ j.seminoncol.2010.05.010 
[5] Seibert LM. Feather-Picking Disorder in Pet Birds. In: Manual of Parrot Behavior [Internet]. John Wiley \& Sons, Ltd; 2006 [cited 2021 May 13]. p. 255-65.

[6] Alupo C. En enkätstudie om psykiskt trauma hos hund. :64.

[7] National Collaborating Centre for Mental Health (UK). Common Mental Health Disorders: Identification and Pathways to Care [Internet]. Leicester (UK): British Psychological Society; 2011 [cited 2021 May 13]. (National Institute for Health and Clinical Excellence: Guidance).

[8] Joel D. Current animal models of obsessive compulsive disorder: A critical review. Progress in NeuroPsychopharmacology and Biological Psychiatry. 2006 May 1;30(3):374-88. https://doi.org/10.1016/j.pnpbp .2005 .11 .006

[9] Grant BF, Saha TD, Ruan WJ, Goldstein RB, Chou SP, Jung J, et al. Epidemiology of DSM-5 Drug Use Disorder. JAMA Psychiatry. 2016 Jan;73(1):39-47. https://doi.org/10.1001/jamapsychiatry.2015.2132

[10] American Psychiatric Association. Diagnostic and Statistical Manual of Mental Disorders. \#5. Washignton, DC: American Psychiatric Publishing; 2013. https://doi.org/10.1176/appi.books.9780890425596

[11] Field M, Kersbergen I. Are animal models of addiction useful? Addiction. 2020;115(1):6-12. https://doi.org/ 10.1111/add.14764

[12] Wolffgramm J, Galli G, Thimm F, Heyne A. Animal models of addiction: models for therapeutic strategies? J Neural Transm (Vienna). 2000 Jan 1;107(6):649-68. https://doi.org/10.1007/s007020070067.

[13] Lamontagne SJ, Olmstead MC. Animal models in addiction research: A dimensional approach. Neuroscience \& Biobehavioral Reviews. 2019 Nov 1;106:91-101. https://doi.org/10.1016/j.neubiorev.2018 .06 .005

[14] Hilderbrand ER, Lasek AW. Studying Sex Differences in Animal Models of Addiction: An Emphasis on Alcohol-Related Behaviors. ACS Chem Neurosci. 2018 Aug 15;9(8):1907-16. https://doi.org/10.1021/ acschemneuro.7b00449

[15] Venniro M, Banks ML, Heilig M, Epstein DH, Shaham Y. Improving translation of animal models of addiction and relapse by reverse translation. Nat Rev Neurosci. 2020 Nov;21(11):625-43. $\quad$ https://doi.org/10.1038/ s41583-020-0378-Z

[16] Gardner EL. Animal Models of Addiction. In: elGuebaly N, Carrà G, Galanter M, Baldacchino AM, editors. Textbook of Addiction Treatment: International Perspectives [Internet]. Cham: Springer International Publishing; 2021 [cited 2021 May 13]. p. 35-49. https://doi.org/10.1007/978-3-030-36391-8_ 4

[17] Spanagel R. Animal models of addiction. Dialogues Clin Neurosci. 2017 Sep;19(3):247-58. https://doi.org/ 10.31887/dens.2017.19.3/rspanagel

Patel | URNCST Journal (2021): Volume 5, Issue 6

DOI Link: $\underline{\text { https://doi.org/10.26685/urncst.267 }}$
[18] Søvik E, Barron AB. Invertebrate Models in Addiction Research. Brain Behav Evol. 2013;82(3):153-65. https://doi.org/10.1159/000355506

[19] Morgan D, Sizemore GM. Animal models of addiction: fat and sugar. Curr Pharm Des. 2011;17(12):1168-72. https://doi.org/10.2174/138161211795656747.

[20] Kim SF. Animal models of eating disorders. Neuroscience. 2012 Jun 1;211:2-12. https://doi.org/ 10.1016/j.neuroscience.2012.03.024

[21] Treasure J, Eid L. Eating disorder animal model. Curr Opin Psychiatry. $2019 \quad$ Nov;32(6):4717. https://doi.org/10.1097/yco.0000000000000550

[22] Avena NM, Bocarsly ME. Dysregulation of brain reward systems in eating disorders: neurochemical information from animal models of binge eating, bulimia nervosa, and anorexia nervosa. Neuropharmacology. $2012 \quad$ Jul;63(1):87-96. https://doi.org/10.1016/j.neuropharm.2011.11.010

[23] Turton R, Chami R, Treasure J. Emotional Eating, Binge Eating and Animal Models of Binge-Type Eating Disorders. Curr Obes Rep. 2017 Jun 1;6(2):217-28. https://doi.org/10.1007/s13679-017-0265-8

[24] Mathes WF, Brownley KA, Mo X, Bulik CM. The biology of binge eating. Appetite. 2009 Jun 1;52(3):545-53. https://doi.org/10.1016/j.appet.2009.03 .005

[25] Gestel M, Kostrzewa E, Adan R, Janhunen S. Pharmacological manipulations in animal models of anorexia and binge eating in relation to humans. undefined [Internet]. 2014 [cited 2021 May 13]; https://doi.org/10.1111/bph.12789

[26] Di Segni M, Patrono E, Patella L, Puglisi-Allegra S, Ventura R. Animal Models of Compulsive Eating Behavior. Nutrients. 2014 Oct 22;6(10):4591-609. https://doi.org/10.3390/nu6104591

[27] Hancock SD, Olmstead MC. Animal Models of Eating Disorders. In: Olmstead MC, editor. Animal Models of Drug Addiction [Internet]. Totowa, NJ: Humana Press; 2011 [cited 2021 May 13]. p. 207-34. (Neuromethods). https://doi.org/10.1007/978-1-60761-934-5 8.

[28] Casper R, Sullivan E, Tecott L. Relevance of animal models to human eating disorders and obesity. Psychopharmacology. $2008 \quad$ Sep 1;199:31329. https://doi.org/10.1007/s00213-008-1102-2

[29] Kurien T, Gross T, Scofield RH. Barbering in mice: a model for trichotillomania. BMJ. 2005 Dec 24;331(7531):1503-5. https://doi.org/10.1136/bmj.331 .7531 .1503

[30] Hart PC, Bergner CL, Dufour BD, Smolinsky AN, Egan RJ, LaPorte JL, et al. ANALYSIS OF ABNORMAL REPETITIVE BEHAVIORS IN EXPERIMENTAL ANIMAL MODELS. :12.

[31] Vieira G de LT, Lossie AC, Jr DCL, Radcliffe JS, Garner JP. Preventing, treating, and predicting barbering: A fundamental role for biomarkers of oxidative stress in a mouse model of Trichotillomania. 
UNDERGRADUATE RESEARCH IN NATURAL AND CLINICAL SCIENCE AND TECHNOLOGY (URNCST) JOURNAL Read more URNCST Journal articles and submit your own today at: https://www.urncst.com

PLOS ONE. 2017 Apr 20;12(4):e0175222. https://doi .org/10.1371/journal.pone.0175222

[32] Feusner JD, Hembacher E, Phillips KA. The mouse who couldn't stop washing: pathologic grooming in animals and humans. CNS Spectr. 2009 Sep;14(9):503-13. https://doi.org/10.1017/s1092852900023567

[33] Walther MR, Ricketts EJ, Conelea CA, Woods DW. Recent Advances in the Understanding and Treatment of Trichotillomania. J Cogn Psychother. 2010 Feb 1;24 (1):46-64. https://doi.org/10.1891/0889-8391.24.1.46

[34] Chamberlain SR, Harries M, Redden SA, Keuthen NJ, Stein DJ, Lochner C, et al. Cortical thickness abnormalities in trichotillomania: international multisite analysis. Brain Imaging Behav. 2018;12(3):823-8. https://doi.org/10.1007/s11682-017-9746-3
[35] Camilla d'Angelo L-S, Eagle DM, Grant JE, Fineberg NA, Robbins TW, Chamberlain SR. Animal models of obsessive-compulsive spectrum disorders. CNS Spectr. 2014 Feb;19(1):28-49. https://doi.org/10.1017/ s1092852913000564

[36] Bordnick PS, Thyer BA, Ritchie BW. Feather picking disorder and trichotillomania: an avian model of human psychopathology. J Behav Ther Exp Psychiatry. 1994 Sep;25(3):189-96. https://doi.org/10.1016/00057916(94)90019-1

[37] Rapoport JL, Ryland DH, Kriete M. Drug Treatment of Canine Acral Lick: An Animal Model of Obsessivecompulsive Disorder. Archives of General Psychiatry. 1992 Jul 1;49(7):517-21. https://doi.org/10.1001/ archpsyc.1992.01820070011002

\section{Article Information}

Managing Editor: Jeremy Y. Ng

Peer Reviewers: Janice Yan, Ricky Chow

Article Dates: Received April 05 21; Accepted May 20 21; Published Jun 3021

\section{Citation}

Please cite this article as follows:

Patel A. Animal models of psychiatric disorders: A literature review. URNCST Journal. 2021 Jun 30: 5(6).

https://urncst.com/index.php/urncst/article/view/267

DOI Link: https://doi.org/10.26685/urncst.267

\section{Copyright}

(c) Arnavi Patel. (2021). Published first in the Undergraduate Research in Natural and Clinical Science and Technology (URNCST) Journal. This is an open access article distributed under the terms of the Creative Commons Attribution License (https://creativecommons.org/licenses/by/4.0/), which permits unrestricted use, distribution, and reproduction in any medium, provided the original work, first published in the Undergraduate Research in Natural and Clinical Science and Technology (URNCST) Journal, is properly cited. The complete bibliographic information, a link to the original publication on http://www.urncst.com, as well as this copyright and license information must be included.
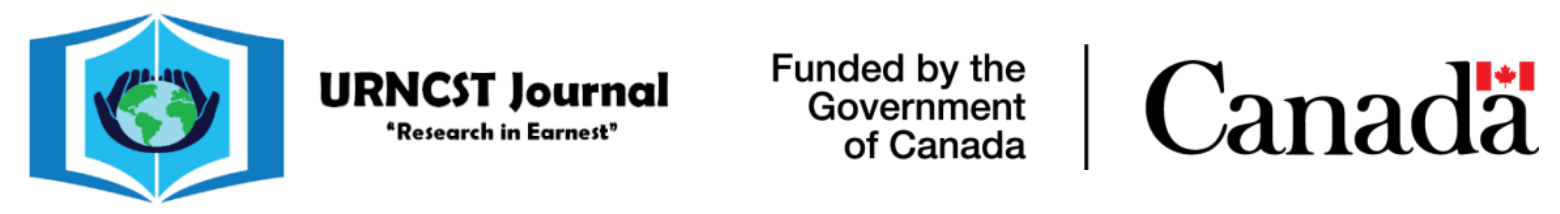

Do you research in earnest? Submit your next undergraduate research article to the URNCST Journal!

| Open Access | Peer-Reviewed | Rapid Turnaround Time | International |

| Broad and Multidisciplinary | Indexed | Innovative | Social Media Promoted |

Pre-submission inquiries? Send us an email at info@ urncst.com | Facebook, Twitter and LinkedIn: @URNCST

Submit YOUR manuscript today at https://www.urncst.com! 